\title{
The Electronic Approaches: The Era of Emergence E-Learning in the Educational System in Iraq
}

\author{
Ahmed Ibrahim Elttayef Al-Abdali, Ali Dakhil Naem Alzayadi
}

\begin{abstract}
This paper aims to show the importance of using technology in Iraqi EFL classrooms to enhance and support education in Iraq especially after the spread of Covid-19all over the world. Iraqi EFL learners suffer from the old method of teaching which depends heavily on following the Grammar Translation Method, the Audio-Lingual Method and recently, the Communicative Approach. Iraq did not attempt to involve e-learning as a tool of learning. Currently, when the world became as a small country especially with the rapid development of technology around the world, it became a necessity to use technology in Iraqi classrooms. Technology has provided a means of escape from all the tradition teaching and learning based on the textbook. Different types of technology provide learners with a vast number of opportunities to develop their English which are not found in the traditional learning. Bataineh and AlAbdali (2015) stated that 'Technology has changed the teachers' and learners' roles, teaching changed from "teacher-centered into student-centered" (P. 243). This paper tries to show teaching and learning English language in the era of E-learning in Iraqi education.
\end{abstract}

Keywords-Electronic Approaches and Educational System in Iraq.

\section{INTRODUCTION}

Technology, nowadays, is regarded a main tool in the educational system of many countries around the world (Al-Abdali, 2016). Several programs and software has been established to work hand in hand with the main sources of learning and teaching that are teacher, student, and textbook (Elttayef, 2016). It is the responsibility of Ministry of Education to adopt using technology in the educational system in Iraq to help Iraqi EFL learners communicate successfully, in English, inside and outside classrooms because technology creates an authentic environment to enable learners study and learn English in an English-like community. It is justified that the use of technology in Iraqi education is much needed.

\section{THE EFFECT OF COVID-19 ON THE WORLD EDUCATIONAL SYSTEMS}

The COVID-19 pandemic has affected educational systems worldwide, leading to the near-total closures of schools, universities and colleges (UNESCO, 2020). Most governments around the world have temporarily closed educational institutions in an attempt to contain the spread of the COVID-19 pandemic. These nationwide closures are impacting over $60 \%$ of the world's student population. Several other countries have implemented localized ISSN: 2456-7620 closures impacting millions of additional learners (UNESCO, 2020). As of 24 May 2020, approximately 1.725 billion learners are currently affected due to school closures in response to the pandemic. According to UNICEF monitoring, 153 countries are currently implementing nationwide closures and 24 are implementing local closures, impacting about 98.6 percent of the world's student population. 10 countries' schools are currently open (UNESCO, 2020).

Online learning has become a critical lifeline for education, as institutions seek to minimize the potential for community transmission (Murphy, 2020). Technology can enable teachers and students to access specialized materials well beyond textbooks, in multiple formats and in ways that can bridge time and space (OECD, 2020). Therefore, due to the COVID-19 pandemic, many schools in over the world in general and in Iraq in specific, began conducting classes via video telephony software such as Zoom, Google Classroom, Google Meet, Free Conference Call, Telegram, etc.

\section{THE EDUCATIONAL SYSTEM IN IRAQ}

It is claimed that in spite of the fact that the utilization of technology in classroom settings can help in encouraging the educating and enhancing the student's learning 
aptitudes, the classrooms in Iraqi universities still do not have the accessibility of this technology because of a few difficulties that the nation faces (Ghareb\& Mohammed, 2017). In comparison to other Arab countries, launching elearning systems in Iraq came at a late stage. Although universities in Iraq are interested in online learning, they have only started using it recently (Ameen et al, 2017).

\section{THE ERA OF E-LEARNING IN IRAQ}

The educational system in Iraq never accept e-learning as a type of learning in Iraq. Nowadays, where all the world suffer from the spread of Covid-19, it became necessary to adopt e-learning in our schools and universities to enable learners continue learning and help education no to stop at all. Digital communication is more dynamic and efficient than traditional methods. Similarly, digital technology can involve learners in "authentic language learning experience" (Bataineh and Al-Abdali, 2014 P. 160). The history of e-learning starts around early 1960s when the University of Illinois established a classroom system equipped with linked computer terminals. Students could access informational resources on a particular course while listening to the lectures (Woolley, 1994). Al-Abdali (2017) expresses that "over the past few years, new different types of methods-technology based had brought into FL classes by many teachers depending on results of a number of researchers that emphasizing the important and the necessity of using technology in classrooms" (p.273).

In the same vein, Abbas and Elttayef (2019) stated that adopting technology in education is vital to develop EFL learners' communicative language. Technology aided language learning has become a popular method of English classes, since it replaced the traditional teaching and learning with digital touch screen methods. Mobiles are the forms of the new teaching and learning methods. This opened the door for learners to get their learning outside and inside classrooms (Al-Abdali and Al-Temimi, 2018, p. 143). Elttayef (2016) emphasized that "With the rapid development of technology, foreign language classes are in need for adopting and utilizing different kinds of technology, in other words, technology should be brought into our classes as effective tools for second language learning and acquisition" (p.39). Furthermore, Bataineh and Al-Abdali (2014) stated that "The new forms of communication is becoming an integral part of modern life finding their place in the language classroom, offering new exciting modes of communication for engaging learners in authentic language learning experiences" (p. 160). Teaching goals cannot be achieved alone without the help of technology (Al-Abdali, 2016).
More importantly, using technology in education in general and in teaching English language in particular has been the goal for many educators for many years. The use of technology in English as a foreign language (EFL) learning and teaching included mobile phone technology, mobile assisted language learning (MALL), computer-mediated communication (CMC), CDs, DVDs, films, iPads, iPods, computer-assisted language learning (CALL), data shows, iPods, intranet, internet, multimedia, etc. These types of technology can be regarded as effective tools in the educational operation (Al-abdali, 2014). Technologies provided the educational system with unlimited various tools and options that enabled learners and teachers in the process of language development (Al-Abdali, 2016). Additionally, technology has changed teacher's practices in teaching and learning because the classroom becamemore student-centered rather than teacher-centered (Bataineh\& Al-Abdali, 2015).

E-Learning, generally, adopts different principles and criteria to what is common to traditional education. These differences stem from the fact that this new approach is based on digital computers and communication lines rather than on timely physical existence in a class. Therefore, a student and an instructor can be thousands of kilometers apart from each other and they can still have productive exchange of interactions. Furthermore, this approach ensures that even time is not an important factor in the process where recorded materials, email and messaging services ensures that recorded lecture viewed on a time later can be as useful as fresh ones. Table 1 provides a useful comparison between the two approaches (ALHuseiny, 2017).

\section{CONCLUSION}

From the previous discussion, the researcher concluded that the educational system in Iraq need to adopt various kinds of E-Learning to support not only teaching and learning English but also all other fields of knowledge. Elearning became a must in Iraqi EFL classrooms in both schools and universities to close the gap of face-to-face learning. Despite the fact that e-learning does not replace teachers' roles, but it can help learners to stay-at-home and stay connected with classes, classmates, and instructors. Elearning enables learners to continue their learning using different software of communication. Iraqi Ministry of Education (MOE) and Ministry of Higher Education and Scientific Research (MOHESR) should accept this kind of learning and manage this learning in the Iraqi curriculum. MOE and MOHESR should train teachers as well as learners how to accept this shifting in the educational 
system from traditional into technology-based one through making more training programs. Form the economical point of view, Iraq can benefit from e-learning to minimize the cost of learning in Iraq and to help learners save time when they can attend lectures outside and inside their homes and classes.

\section{REFERENCES}

[1] Abbas, Z. \&Elttayef, A. (2019). The Importance of Using Information Communication Technology (ICT) for Teaching English Language in Public Schools in Iraq Transylvanian Review, 27, 2019.

[2] Al-Abdali, A. (2016). The Role of Online Internet-Cam Chat in Providing EFL Freshmen with Opportunities to Interact with the Target Language Community as an Authentic Environment to Develop Communicative Language Skills. British Journal of English Linguistics. Vol.4, No.4, pp.4659, July 2016.

[3] Al-Abdali, A. (2017). Blog Assisted Language Learning (BALL): The Pedagogical Value of Using Audio-Textual Blog on Improving Learners' Proficiency, Cultural Competence, and Motivation. Misan Journal of Academic Studies 2017.

[4] Al-Abdali, A. (2017). Developing the Wireless Digital Technology: Using Short and Multimedia Messaging Services to Improve the Fluency and Accuracy Competences of the EFL Learners: An Experimental Study. Al-Utroha. Vo. 7. 2017.

[5] Al-Abdali, A. Al-Temimi, Z. (2018). Technology Assisted Language Learning: The Pedagogical Orientation of Using Mobiles for Academic Purposes to Improve Language Communication Skills of the University Students: An Experimental Study. Translation \& Linguistics, Vol. 12. June 2018.

[6] AL-Huseiny, M. (2017). An e-Learning Environment Based on the Moodle Platform for Iraq Universities. Wasit Journal for Engineering Sciences Vol3.Iss2.39

[7] Ameen, N., Willis, R., and Abdullah, M., (2017). The use of e-learning by students in Iraqi universities: Potential and challenges. 8th International Visible Conference on Educational Studies \& Applied Linguistics 2017 ISBN 9780-9962570-7-7

[8] Bataineh, A. \& Al-Abdali (2014). The effect of using webcam Chat on Jordanian English major students' paralinguistic competence. International Journal of Education. Vol. 6, No. 2

[9] Bataineh A. \& Al-Abdali, A. (2015). The Effect of Using Web-Cam Chat on the Undergraduate EFL learners' SocioCultural Competence. International Journal of Education 2015, Vol. 7, No. 2

[10] "COVID-19 Educational Disruption and Response". UNESCO. 2020-03-04. Retrieved 2020-04-12.

[11] Elttayef. A. (2016). Future Digital Touch-Based Curricula: Touch Screen-Based Interaction and itsEducational Impact on Developing EFL Learners' Linguistic Competence.
British Journal of English Linguistics. Vol.4, No.6, pp.3949, November 2016

[12] Ghareb, M. \& Mohammed, S. (2017). The Future of Technology-based Classroom. UHD Journal of Science and Technology | April 2017 | Vol 1 | Issue 1

[13] Murphy, Michael P. A. (2020-04-30). "COVID-19 and emergency eLearning: Consequences of the securitization of higher education for post-pandemic pedagogy". Contemporary Security Policy. 0: 1 14. doi:10.1080/13523260.2020.1761749. ISSN 1352-3260.

[14] Oecd (2020). LEARNING REMOTELY WHEN SCHOOLS CLOSE. https://read.oecdilibrary.org/view/?ref=127_127063iiwm328658\&title=Learning-remotely-when-schools-close

[15] Woolley D. R., 1994, PLATO: The Emergence of Online Community., [cited 2015 July], Thinkofit.comhttps://plus.google.com/+UNESCO (2020-0304). "COVID-19 Educational Disruption and Response". UNESCO. Retrieved 2020-05-24. 